\title{
Neutron diffraction in gemology: Single-crystal diffraction study of brazilianite, $\mathrm{NaAl}_{3}\left(\mathrm{PO}_{4}\right)_{2}(\mathrm{OH})_{4}$
}

\author{
G. Diego Gatta, ${ }^{1, *}$ Pietro Vignola, ${ }^{1}$ Martin Meven, ${ }^{2,3}$ And Romano Rinaldi ${ }^{4}$ \\ ${ }^{1}$ Dipartimento di Scienze della Terra, Università degli Studi di Milano, Via Botticelli 23, I-20133 Milano, Italy \\ ${ }^{2}$ Institut für Kristallographie, RWTH Aachen, Jägerstrasse 17-19, D-52056 Aachen, Germany \\ ${ }^{3} J$ ülich Centre for Neutron Science, Forschungszentrum Jülich GmbH, Outstation at FRM II, Lichtenbergstrasse 1, D-85747 Garching, Germany \\ ${ }^{4}$ Dipartimento di Scienze della Terra, Università degli Studi di Perugia, Piazza Università 1, I-06123 Perugia, Italy
}

\begin{abstract}
The chemical composition and the crystal structure of a gem-quality brazilianite from the Telírio pegmatite, near Linópolis, Minas Gerais, Brazil, $\left[\mathrm{NaAl}_{3}\left(\mathrm{PO}_{4}\right)_{2}(\mathrm{OH})_{4}, a=11.2448(5) \AA, b=10.1539(6)\right.$ $\AA, c=7.1031(3) \AA, \beta=97.351(4)^{\circ}, V=804.36(7) \AA^{3}$, space group $\left.P 2_{1} / n, Z=4\right]$, have been reinvestigated by means of electron microprobe analysis in wavelength-dispersive mode, single-crystal X-ray and neutron diffraction. The chemical analysis shows that brazilianite from Telírio Claim approaches almost ideal composition. The neutron anisotropic structural refinement was performed with final agreement index $R_{1}=0.0290$ for 211 refined parameters and 2844 unique reflections with $F_{\mathrm{o}}>4 \sigma\left(F_{\mathrm{o}}\right)$, the X-ray refinement led to $R_{1}=0.0325$ for 169 refined parameters and 2430 unique reflections with $F_{\mathrm{o}}>4 \sigma\left(F_{\mathrm{o}}\right)$. The building-block units of the brazilianite structure consist of chains of edge-sharing $\mathrm{AlO}_{4}(\mathrm{OH})_{2}$ and $\mathrm{AlO}_{3}(\mathrm{OH})_{3}$ octahedra. Chains are connected, via corner-sharing, by P-tetrahedra to form a three-dimensional framework, with $\mathrm{Na}$ atoms located in distorted cavities running along [100]. Five independent $\mathrm{H}$ sites were located, here labeled as $\mathrm{H}(1), \mathrm{H}(2 \mathrm{a}), \mathrm{H}(2 \mathrm{~b}), \mathrm{H}(3)$, and $\mathrm{H}(4)$. The configuration of the $\mathrm{OH}$ groups, along with the complex hydrogen-bonding scheme, are now well defined. The $\mathrm{O}-\mathrm{H}$ distances corrected for "riding motion" range between $\sim 0.992$ and $\sim 1.010 \AA$, the $\mathrm{O} \cdots \mathrm{O}$ distances between $\sim 2.67$ and $\sim 2.93 \AA$, and the $\mathrm{O}-\mathrm{H} \cdots \mathrm{O}$ angles between $\sim 151^{\circ}$ and $\sim 174^{\circ}$. The $\mathrm{H}(2 \mathrm{a})$ and $\mathrm{H}(2 \mathrm{~b})$ are only $\sim 1.37 \AA$ apart and mutually exclusive (both with site occupancy factor of $50 \%$ ). The differences between the crystal structure of brazilianite and wardite [ideally $\mathrm{NaAl}_{3}\left(\mathrm{PO}_{4}\right)_{2}(\mathrm{OH})_{4} \cdot 2 \mathrm{H}_{2} \mathrm{O}$ ] are discussed. This work fulfills the need for accurate crystal-chemical data for this gem mineral.
\end{abstract}

Keywords: Brazilianite, crystal chemistry, single-crystal neutron diffraction, hydrogen bonding

\section{INTRODUCTION}

Brazilianite, ideally $\mathrm{NaAl}_{3}\left(\mathrm{PO}_{4}\right)_{2}(\mathrm{OH})_{4}$, commonly forms equant to elongated monoclinic crystals with yellow to yellowish-green color, mainly found in large pockets in the platy albite (cleavelandite) units of granitic pegmatites. In granitic pegmatites, brazilianite is considered to form as a product of Na-metasomatic alteration of montebrasite-amblygonite. The type locality of this mineral, from which the name brazilianite, is the Corrego Frio pegmatite, Minas Gerais, Brazil, where it was first discovered in 1944 (Pough and Henderson 1945; Pecora and Fahey 1949). Brazilianite also occurs in phosphate-rich sedimentary deposits, e.g., Yukon Territories, Big Fish River, Stoneham Camp.

Brazilianite usually occurs in the form of perfect crystals (typically short prismatic, spearhead shaped, elongated along [100], usually with $\{011\},\{\overline{1} 11\},\{010\},\{110\},\{\overline{3} 01\}$, and $\{101\})$, grouped in druses and rarely as larger gem-quality crystals (Pough and Henderson 1945; Hurlbut and Weichel 1946; Frondel and Lindberg 1948; Pecora and Fahey 1949; Macrì 2011). The most important deposit of brazilianite is in the surroundings of Conselheiro Pena, in the state of Minas

*E-mail: diego.gatta@unimi.it
Gerais. During the past few years, this deposit has yielded a great quantity of beautiful raw material, including dark greenishyellow to olive-green crystals of surprisingly large dimensions (i.e., up to $10 \mathrm{~cm}$ in length and width) and perfectly bounded crystal faces. Crystals of similar shape and dimensions were discovered in another deposit in Minas Gerais, near Mantena. Minor deposits are those at the Palermo no. 1 Mine and G.E. Smith mine in New Hampshire, U.S.A. Brazilianite is one of the few phosphate minerals to be used as a gemstone (along with amblygonite, turquoise, and some gem varieties of apatite), and is relatively new to the gemstones market. The Mohs hardness of brazilianite is 5.5. The refraction indexes for the $\alpha, \beta$, and $\gamma$ rays are $1.602,1.609$, and $1.621-1.623$, respectively. It is biaxial positive, with a birefringence of $0.019-0.021$, and the dispersion is low (O’Donoghue 2006).

Only a few studies have so far been devoted to the crystal chemistry of brazilianite (Frondel and Lindberg 1948, and references therein). Its crystal structure was solved by Gatehouse and Miskin (1974), on the basis of single-crystal X-ray diffraction data, in the space group $P 2_{1} / n$, with $a \sim 11.23 \AA, b \sim 10.14 \AA, c$ $\sim 7.10 \AA$, and $\beta \sim 97.4^{\circ}(Z=4)$. Its structure consists of chains of edge-sharing Al-octahedra linked by P-tetrahedra forming a three-dimensional network, with $\mathrm{Na}$ atoms located in cavities 
parallel to [100] (Fig. 1). In the structure model of Gatehouse and Miskin (1974), there are two different configurations of the Al-octahedra: trans- $\mathrm{AlO}_{4}(\mathrm{OH})_{2}$ and trans- $\mathrm{AlO}_{3}(\mathrm{OH})_{3}$.

The general structure model of brazilianite reported by Gatehouse and Miskin (1974) appears to be consistent. However, the refinement included anisotropic displacement parameters only for the cation sites. In addition, the positions of the four independent proton sites appear to be affected by high uncertainties, as expected for X-ray refinements at that time, and the isotropic thermal parameters were not refined. This led to a poor description of the complex H-bonding scheme in the brazilianite crystal structure. In this light, the aim of the present study is a reinvestigation of the crystal structure and crystal chemistry of a natural brazilianite (from Telírio) at ambient temperature by means of single-crystal X-ray and neutron diffraction and electron microprobe analysis in wavelength-dispersive mode, to provide: (1) the reliable location of the proton sites and the real topological configuration of the $\mathrm{OH}$-groups, for a full description of the atomic relationship via the H-bonds; (2) the anisotropic displacement parameters of all the atomic sites, $\mathrm{H}$ sites included. This experiment follows a series of crystal structure investigations we have recently performed on gemstone minerals containing light elements $(\mathrm{H}, \mathrm{Li}, \mathrm{Be}$, and $\mathrm{B})$ by single-crystal neutron diffraction (Gatta et al. 2010, 2012a, 2012b), a method offering definite advantages in these cases (Rinaldi et al. 2009).

\section{SAMPLES DESCRIPTION AND MINERALOGY}

A prismatic single crystal of pale yellow, gem-quality brazilianite (18 $\mathrm{mm}$ length and $5 \mathrm{~mm}$ width) from the Telírio pegmatite, near the village of Linópolis (not far from the Corrego Frio mine, type locality for brazilianite), in the Divino das Laranjeiras district (Minas Gerais, Brazil), was used for the chemical analysis and for the diffraction experiments of this study. The pegmatite field of East Minas Gerais is hosted by metamorphic rocks, belonging to the Precambrian shield, and consists of beryl- to complex-type granitic pegmatites, following the classification of Černý and Ercit (2005), which are rich in gemstones. Such pegmatites are mined by local miners (frequently a single mine, garimpo, is owned and mined by a single family of miners locally called garimpeiros) for gemstones (e.g., beryl, topaz, and tourmaline). The Telírio dike is a zoned pegmatite, with a well-developed $\mathrm{Na}$-metasomatic unit and large pockets in cleavelandite containing brazilianite crystals up to 10 $\mathrm{cm}$. The brazilianite crystal used in this study was perched on platy albite $(3 \times 3 \times 2 \mathrm{~cm}$ of cleavelandite $)$ and closely associated with zanazziite crystals (up to $3 \mathrm{~mm}$ ).

\section{EXPERIMENTAL METHODS}

A preliminary check of the crystal of brazilianite chosen for this study was done under polarized light, showing that it was free of twinning, growth sectors, or inclusions. The crystal was then cut into several pieces, to perform chemical analysis, $\mathrm{X}$-ray, and neutron diffraction experiments.

One fragment of the original single crystal of brazilianite was used for the quantitative electron microprobe analysis in wavelength-dispersive mode (EPMA-WDS) using a Jeol JXA-8200 electron microprobe at the Earth Science Department of the University of Milano (ESD-UMI). The crystal fragment was mounted in epoxy resin, polished, and carbon coated. Major and minor elements were determined at $15 \mathrm{kV}$ accelerating voltage, $5 \mathrm{nA}$ beam current, and $3 \mu \mathrm{m}$ beam diameter using a counting time of $30 \mathrm{~s}$ on the peaks and $10 \mathrm{~s}$ on the backgrounds. The following elements were analyzed: $\mathrm{P}, \mathrm{Al}, \mathrm{Fe}, \mathrm{Mn}, \mathrm{Ba}, \mathrm{Sr}, \mathrm{Ca}, \mathrm{Mg}, \mathrm{Na}, \mathrm{K}, \mathrm{F}$, and $\mathrm{Cl}$, using a series of well-characterized natural minerals as standards (graftonite for $\mathrm{P}$, anorthite for $\mathrm{Al}$, fayalite for $\mathrm{Fe}$, rhodonite for $\mathrm{Mn}$, barite for $\mathrm{Ba}$, celestine for $\mathrm{Sr}$, wollastonite for $\mathrm{Ca}$, forsterite for $\mathrm{Mg}$, omphacite for $\mathrm{Na}$, $\mathrm{K}$-feldspar for $\mathrm{K}$, topaz for $\mathrm{F}$, and sodalite for $\mathrm{Cl}$ ). The data were corrected for matrix effects using a conventional $\Phi \rho Z$ routine available in the Jeol suite of programs. A total number of 16 point analysis were performed, and the crystal was found to be homogeneous within the analytical error. The average chemical composition and the proportional formula are given in Table 1.

Two further fragments of the original large crystal, of approximately $4.2 \times 3.6$ $\times 2.8 \mathrm{~mm}^{3}$ and $0.35 \times 0.32 \times 0.20 \mathrm{~mm}^{3}$, were selected for the neutron and X-ray diffraction experiments, respectively. X-ray intensity data were collected at 293 $\mathrm{K}$ and up to $2 \theta_{\max }=72.67^{\circ}$ (with $-18 \leq h \leq 18,-13 \leq k \leq 13$, and $-11 \leq l \leq 11$, Table 2) with an Xcalibur diffractometer at the ESD-UMI, equipped with CCD, monochromatized $\mathrm{MoK} \alpha$ radiation and operated at $50 \mathrm{kV}$ and $40 \mathrm{~mA}$. The data collection was performed with a combination of $\varphi / \omega$ scans, step size of $1^{\circ}$ and an exposure time of $5 \mathrm{~s} /$ frame. A total number of 20604 Bragg reflections (with a high degree of redundancy) were collected, giving a metrically monoclinic unit cell with: $a=11.2448(5), b=10.1539(6), c=7.1031(3) \AA, \beta=97.351(4)^{\circ}$, and $V$ $=804.4 \AA^{3}$ (Table 2). The systematic absences suggested the space group $P 2_{1} / n$, as previously reported by Gatehouse and Miskin (1974). The intensity data were then integrated and corrected for Lorentz-polarization effects, using the computer program CrysAlis (Agilent Technologies 2012). An analytical absorption correction was applied by Gaussian integration based upon the physical description of the crystal (CrysAlis, Agilent Technologies 2012). After the corrections, the discrepancy factors among symmetry-related reflections (Laue class: $2 / m$ ) was $R_{\text {int }}=0.0392$ (Table 2).

The single-crystal neutron diffraction experiment was performed using the hot source (fast neutrons) single-crystal diffractometer HEiDi of the neutron source Forschungs-Neutronenquelle Heinz Maier-Leibnitz (FRM II). The diffraction data were collected at $293 \mathrm{~K}$, with a wavelength of the incident beam of 0.7935 (2) Å. A ${ }^{3} \mathrm{He}$ single counter detector was used [Eurisys $73 \mathrm{NH} 17 / 5 \mathrm{X}$ end window counter, $50 \mathrm{~mm}$ entrance window, 5 bar ${ }^{3} \mathrm{He}$ pressure, and $170 \mathrm{~mm}$ active length for high
Figure 1. Two views of the crystal structure of brazilianite (i.e., down [100] and [001]) based on the neutron structure refinement of this study. Thermal ellipsoid probability factor: $60 \%$. Al-octahedra are in light gray, P-tetrahedra in dark gray, $\mathrm{Na}$ sites (medium gray) as un-bonded atoms, $\mathrm{H}$ sites in white.

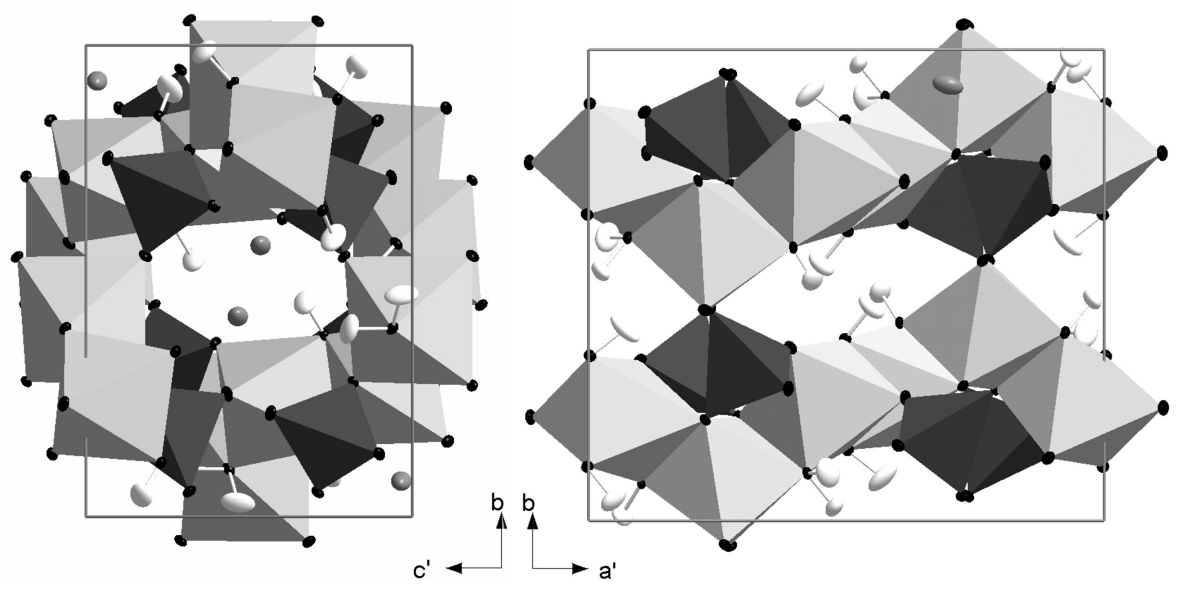


TABLE 1. Representative compositions of brazilianite from Telírio, based on EPMA-WDS analysis (16 data points)

\begin{tabular}{lrlll}
\hline & wt\% & e.s.d & \multicolumn{2}{c}{ lons (apfu) } \\
\hline $\mathrm{P}_{2} \mathrm{O}_{5}$ & 39.26 & 0.48 & $\mathrm{P}$ & 2.000 \\
$\mathrm{Al}_{2} \mathrm{O}_{3}$ & 42.40 & 0.38 & $\mathrm{Al}$ & 3.007 \\
$\mathrm{Fe}_{2} \mathrm{O}_{3}$ & 0.04 & 0.03 & $\mathrm{Fe}^{3+}$ & 0.002 \\
$\mathrm{MgO}$ & 0.04 & 0.03 & $\mathrm{Mg}$ & 0.003 \\
$\mathrm{SrO}$ & 0.05 & 0.05 & $\mathrm{Sr}$ & 0.002 \\
$\mathrm{CaO}$ & 0.03 & 0.01 & $\mathrm{Ca}$ & 0.002 \\
$\mathrm{Na}_{2} \mathrm{O}$ & 8.18 & 0.18 & $\mathrm{Na}$ & 0.955 \\
$\mathrm{~K}_{2} \mathrm{O}$ & 0.01 & 0.01 & $\mathrm{~K}$ & 0.001 \\
$\mathrm{H}_{2} \mathrm{O}^{*}$ & 9.41 & & $\mathrm{OH}^{-}$ & 4.001 \\
Total & 99.41 & & & \\
\hline
\end{tabular}

Notes: Formula proportions calculated on the basis of 2 atoms of $\mathrm{P}$ per formula unit (apfu). $\mathrm{Mn}, \mathrm{Ba}, \mathrm{Cl}$, and $\mathrm{F}$ below detection limit.

* Calculated on the basis of $4 \mathrm{OH}^{-}$apfu.

TABLE 2. Details of the X-ray and neutron data collection and refinements of brazilianite

\begin{tabular}{|c|c|c|}
\hline Crystal shape & Prismatic & Prismatic \\
\hline Crystal size $\left(\mathrm{mm}^{3}\right)$ & $4.2 \times 3.6 \times 2.8$ & $0.35 \times 0.32 \times 0.20$ \\
\hline Crystal color & Translucent pink & Translucent pink \\
\hline Unit-cell constants & $\begin{array}{c}a=11.243(2) \AA \\
b=10.154(2) \AA \\
c=7.115(1) \AA \\
\beta=97.32(2)^{\circ}\end{array}$ & $\begin{array}{c}a=11.2448(5) \AA \\
b=10.1539(6) \AA \\
c=7.1031(3) \AA \\
\beta=97.351(4)^{\circ}\end{array}$ \\
\hline $\begin{array}{l}\text { Reference chemical formula } \\
\text { Space Group }\end{array}$ & $\begin{array}{c}\mathrm{NaAl}_{3}\left(\mathrm{PO}_{4}\right)_{2}(\mathrm{OH})_{4} \\
P 2 / n\end{array}$ & $\begin{array}{c}\mathrm{NaAl}_{3}\left(\mathrm{PO}_{4}\right)_{2}(\mathrm{OH})_{4} \\
P 2 / n\end{array}$ \\
\hline$Z$ & 4 & 4 \\
\hline$T(\mathrm{~K})$ & 293 & 293 \\
\hline$\rho_{\text {calc }}\left(\mathrm{g} / \mathrm{cm}^{3}\right)$ & 2.984 & 2.989 \\
\hline Radiation $(\AA)$ & Neutron, $0.7935(2)$ & X-ray, MoK $\alpha$ \\
\hline Diffractometer & HEiDi, four circle & XCalibur-CCD \\
\hline
\end{tabular}

Scan type

\section{Data-collection strategy}

$$
\begin{gathered}
31 \text { steps, } \\
\omega \text {-scan at } 2 \theta<55^{\circ} \\
\omega / 2 \theta-\operatorname{scan} \text { at } 2 \theta \geq 55^{\circ}
\end{gathered}
$$

Time per step (s)

Width; $u, v, q$

Max. $2 \theta\left(^{\circ}\right)$

\begin{tabular}{c}
5 \\
$5.4,-12.0,16.3$ \\
80.07 \\
$-18 \leq h \leq 18$ \\
$-16 \leq k \leq 16$ \\
$-11 \leq I \leq 11$ \\
6321 \\
3461 \\
2844 \\
211 \\
0.0261 \\
0.0290 \\
0.0462 \\
0.0474 \\
1.343 \\
$0.01,0$ \\
$+0.9 /-0.9$ \\
\hline
\end{tabular}

$\omega-\varphi$ scans

5
$1^{\circ}$
72.67
$-18 \leq h \leq 18$
$-13 \leq k \leq 13$
$-11 \leq I \leq 11$
$20604^{*}$
2968
2430
169
0.0392
0.0325
0.0548
0.0487
1.422
$0.01,0$
$+0.4 /-0.4$

No. measured reflections

No. unique reflections

No. unique refl. with $F_{\mathrm{o}}>4 \sigma\left(F_{\mathrm{o}}\right)$

No. refined parameters

$R_{\text {int }}$

$R_{1}(F)$ with $F_{\mathrm{o}}>4 \sigma\left(F_{\mathrm{o}}\right)$

$R_{1}(F)$ for all the unique refl.

$W R_{2}\left(F^{2}\right)$

$S$

Weighting scheme: $a, b$

Residuals ( $\mathrm{fm} / \AA^{3}$ )

$+0.4 /-0.4$

Notes: $R_{\text {int }}=\Sigma \mid F_{\text {obs }}^{2}-F_{\text {obs }}^{2}($ mean $)\left|/ \Sigma\left[F_{\text {obs }}^{2}\right] ; R_{1}=\Sigma\left(\left|F_{\text {obs }}\right|-\left|F_{\text {calc }}\right|\right) / \Sigma\right| F_{\text {obs }} \mid ; w R_{2}=\left\{\Sigma\left[w\left(F_{\text {obs }}^{2}\right.\right.\right.$ $\left.\left.\left.-F_{\text {calc }}^{2}\right)^{2}\right] / \Sigma\left[w\left(F_{\text {obs }}^{2}\right)^{2}\right]\right\}^{0.5}, w=1 /\left[\sigma^{2}\left(F_{\text {obs }}^{2}\right)+(a P)^{2}+b P\right], P=\left[\operatorname{Max}\left(F_{\text {obs }}^{2} 0\right)+2 F_{\text {calc }}^{2}\right] / 3$. Neutron $\omega$-scan width: $\left(u+v \tan \theta+q \tan ^{2} \theta\right)^{0.5}$.

* High degree of redundancy.

detection probability ( $>99 \%$ at $1.0 \AA$ ), separation of $\gamma$ radiation by pulse height discrimination]. The unit-cell parameters were refined on the basis of the $40 \mathrm{Bragg}$ reflections. A total number of 6321 reflections were collected (with $-18 \leq h \leq 18$, $-16 \leq k \leq 16$, and $-11 \leq l \leq 11$, rocking $(=\omega)$ scans below and $\omega / 2 \theta$ scans above $2 \theta=55^{\circ}, 2 \theta_{\max }=80.07^{\circ}$, Table 2 ). The reflection conditions agreed with the space group $P 2_{1} / n$. Integrated intensities were then corrected for Lorentz effect, and no absorption correction was applied, because of the shape and the dimensions of the sample. The discrepancy factor for the symmetry related reflections was $R_{\text {int }}=$ 0.0261. Further details of the data collection are reported in Table 2.

\section{STRUCTURE REFINEMENTS}

The X-ray intensity data of brazilianite were first processed with the program E-STATISTICS, implemented in the WinGX package (Farrugia 1999). The Wilson plot and the statistics of distributions of the normalized structure factors ( $E$ values) suggested that the structure of brazilianite is centrosymmetric at $84.3 \%$ likelihood. On this basis, and considering the reflections conditions, the anisotropic crystal structure refinement was then performed in the space group $P 2_{1} / n$ using the SHELX-97 software (Sheldrick 1997, 2008), starting from the structure model of Gatehouse and Miskin (1974). The neutral scattering factors of $\mathrm{Na}, \mathrm{Al}, \mathrm{P}, \mathrm{O}$, and $\mathrm{H}$ were used according to the International Tables of Crystallography (Wilson and Prince 1999). The secondary isotropic extinction effect was corrected according to Larson's formalism (1967), as implemented in the SHELXL-97 package (Sheldrick 1997, 2008). The first cycles of refinement were conducted without any $\mathrm{H}$ site. When convergence was achieved, no significant correlation was observed among the refined parameters in the variance-covariance matrix. All the principal mean square atomic displacement parameters were positively defined. The last cycles of refinement were conducted adding the $\mathrm{H}$ sites on the basis of the neutron structure refinement (see below), and their coordinates were not refined. At the end of the last cycle of refinement, no peak larger than $+0.4 /-0.4 e^{-} / \AA^{3}$ was present in the final difference-Fourier map of the electron density (Table 2). The final agreement index $\left(R_{1}\right)$ was 0.0325 for 169 refined parameters and 2430 unique reflections with $F_{\mathrm{o}}>4 \sigma\left(F_{\mathrm{o}}\right)$ (Table 2). Site positions and displacement parameters $\left(U_{\mathrm{ij}}\right)$ are reported in Table $3 \mathrm{a}$. Principal root-mean-square components of the atomic displacement parameters are given in Table 4a. Bond lengths and angles are listed in Table 5. (CIFs ${ }^{1}$ are available on deposit.)

The single-crystal neutron diffraction data of brazilianite were first processed following the same protocol described for the X-ray data. The structure was found to be centrosymmetric at $96.2 \%$ likelihood. The anisotropic structure refinement was then performed in the space group $P 2_{1} / n$ using the SHELX-97 software (Sheldrick 1997, 2008), starting from the atomic coordinates of the model of Gatehouse and Miskin (1974) without any $\mathrm{H}$ site. The neutron scattering lengths of $\mathrm{Na}, \mathrm{Al}, \mathrm{P}, \mathrm{O}$, and $\mathrm{H}$ were used according to Sears (1986). The secondary isotropic extinction effect was corrected according to Larson (1967). When convergence was achieved, five intense negative residual peaks were found in the final difference-Fourier map of the nuclear density. As hydrogen has a negative neutron scattering length, further refinement cycles were then performed assigning $\mathrm{H}$ to these residual peaks [i.e., $\mathrm{H}(1), \mathrm{H}(2 \mathrm{a}), \mathrm{H}(2 \mathrm{~b}), \mathrm{H}(3)$, and $\mathrm{H}(4)$ sites; Fig. 2, Table 3b]. The final least-square cycles were conducted with anisotropic thermal parameters for all sites ( $\mathrm{H}$ sites included). The convergence was achieved with all the principal mean square atomic displacement parameters positively defined. The variance-covariance matrix showed no significant correlation among the refined parameters at the end of the refinement. No peak larger than $+0.9 /-0.9 \mathrm{fm} / \AA^{3}$ was present in the final difference-Fourier map of the nuclear density (Table 2). The final agreement index $\left(R_{1}\right)$ was 0.0290 for 211 refined parameters

\footnotetext{
${ }^{1}$ Deposit item AM-13-807, CIFs. Deposit items are available two ways: For a paper copy contact the Business Office of the Mineralogical Society of America (see inside front cover of recent issue) for price information. For an electronic copy visit the MSA web site at http://www.minsocam.org, go to the American Mineralogist Contents, find the table of contents for the specific volume/issue wanted, and then click on the deposit link there.
} 
TABLE 3a. Atomic coordinates and displacement parameters $\left(\AA^{2}\right)$ of brazilianite based on the $X$-ray structure refinement

\begin{tabular}{|c|c|c|c|c|c|c|c|c|c|c|}
\hline & $x / a$ & $y / b$ & $c / z$ & $U_{\text {eq }} / U_{\text {iso }}$ & $U_{11}$ & $U_{22}$ & $U_{33}$ & $U_{12}$ & $U_{13}$ & $U_{23}$ \\
\hline $\mathrm{Na}$ & $0.30332(7)$ & $0.07508(6)$ & $0.03476(9)$ & $0.0239(2)$ & $0.0403(4)$ & $0.0155(4)$ & $0.0166(3)$ & $-0.0053(3)$ & $0.0065(3)$ & $0.0006(3)$ \\
\hline $\mathrm{Al}(1)$ & $0.04325(4)$ & $0.22069(4)$ & $0.56161(5)$ & $0.0058(1)$ & $0.0063(2)$ & $0.0066(2)$ & $0.0046(2)$ & $0.0002(2)$ & $0.0015(1)$ & $-0.0003(2)$ \\
\hline $\mathrm{Al}(2)$ & $0.26290(3)$ & $0.06750(4)$ & $0.50805(5)$ & $0.0057(1)$ & $0.0052(2)$ & $0.0058(2)$ & $0.0061(2)$ & $0.0000(2)$ & $0.0010(1)$ & $-0.0005(2)$ \\
\hline $\mathrm{Al}(3)$ & $0.45940(4)$ & $0.25420(4)$ & $0.43268(5)$ & $0.0055(1)$ & $0.0058(2)$ & $0.0061(2)$ & $0.0047(2)$ & $0.0001(2)$ & $0.0015(1)$ & $0.0005(2)$ \\
\hline$P(1)$ & $0.18049(3)$ & $0.31231(4)$ & $0.23748(4)$ & $0.00506(7)$ & $0.0049(2)$ & $0.0057(2)$ & $0.0045(1)$ & $0.0002(1)$ & $0.0005(1)$ & $0.0007(1)$ \\
\hline$P(2)$ & $0.31236(3)$ & $0.32791(4)$ & $0.75393(4)$ & $0.00478(7)$ & $0.0050(2)$ & $0.0050(2)$ & $0.0044(1)$ & $-0.0004(1)$ & $0.0007(1)$ & $-0.0005(1)$ \\
\hline $\mathrm{O}(1)$ & $0.10330(8)$ & $0.07984(9)$ & $0.44944(12)$ & $0.0067(2)$ & $0.0059(4)$ & $0.0067(5)$ & $0.0074(4)$ & $-0.0003(4)$ & $0.0003(3)$ & $-0.0020(4)$ \\
\hline $\mathrm{O}(2)$ & $0.42379(8)$ & $0.10107(9)$ & $0.56258(12)$ & $0.0073(2)$ & $0.0068(4)$ & $0.0078(5)$ & $0.0073(4)$ & $-0.0006(4)$ & $0.0004(3)$ & $0.0003(4)$ \\
\hline $\mathrm{O}(3)$ & $0.00300(8)$ & $0.34973(9)$ & $0.72421(12)$ & $0.0072(2)$ & $0.0082(4)$ & $0.0069(5)$ & $0.0070(4)$ & $-0.0012(4)$ & $0.0023(3)$ & $-0.0014(4)$ \\
\hline $\mathrm{O}(4)$ & $0.49748(8)$ & $0.38585(9)$ & $0.26989(12)$ & $0.0074(2)$ & $0.0091(5)$ & $0.0072(5)$ & $0.0059(4)$ & $-0.0004(4)$ & $0.0012(3)$ & $0.0004(4)$ \\
\hline O(5) & $0.11484(8)$ & $0.23907(10)$ & $0.06731(13)$ & $0.0087(2)$ & $0.0073(5)$ & $0.0106(5)$ & $0.0079(4)$ & $0.0000(4)$ & $-0.0009(3)$ & $-0.0018(4)$ \\
\hline $\mathrm{O}(6)$ & $0.28766(8)$ & $0.22135(9)$ & $0.31813(12)$ & $0.0071(2)$ & $0.0068(4)$ & $0.0075(5)$ & $0.0070(4)$ & $0.0001(4)$ & $0.0007(3)$ & $0.0007(4)$ \\
\hline $\mathrm{O}(7)$ & $0.22619(8)$ & $0.21329(9)$ & $0.68151(12)$ & $0.0069(2)$ & $0.0075(4)$ & $0.0065(5)$ & $0.0069(4)$ & $-0.0010(4)$ & $0.0013(3)$ & $-0.0017(4)$ \\
\hline $\mathrm{O}(8)$ & $0.38755(8)$ & $0.28025(10)$ & $0.93465(12)$ & $0.0080(2)$ & $0.0067(4)$ & $0.0107(5)$ & $0.0064(4)$ & $0.0000(4)$ & $-0.0002(3)$ & $0.0013(4)$ \\
\hline O(9) & $0.09990(8)$ & $0.34050(9)$ & $0.39257(12)$ & $0.0077(2)$ & $0.0081(4)$ & $0.0077(5)$ & $0.0080(4)$ & $0.0011(4)$ & $0.0037(3)$ & $0.0007(4)$ \\
\hline $\mathrm{O}(10)$ & $0.39145(8)$ & $0.36733(10)$ & $0.60223(12)$ & $0.0077(2)$ & $0.0092(5)$ & $0.0075(5)$ & $0.0071(4)$ & $-0.0016(4)$ & $0.0037(3)$ & $-0.0005(4)$ \\
\hline $\mathrm{O}(11)$ & $0.22579(8)$ & $0.44660(9)$ & $0.18273(12)$ & $0.0088(2)$ & $0.0105(5)$ & $0.0081(5)$ & $0.0080(4)$ & $-0.0012(4)$ & $0.0017(3)$ & $0.0014(4)$ \\
\hline $\mathrm{O}(12)$ & $0.23569(8)$ & $0.44836(9)$ & $0.79031(12)$ & $0.0075(2)$ & $0.0071(4)$ & $0.0072(5)$ & $0.0081(4)$ & $0.0010(4)$ & $0.0003(3)$ & $-0.0008(4)$ \\
\hline$H(1)$ & 0.06558 & 0.01329 & 0.36283 & $0.058(7)$ & & & & & & \\
\hline $\mathrm{H}(2 \mathrm{a})$ & 0.46380 & 0.10177 & 0.69397 & $0.05(1)$ & & & & & & \\
\hline$H(2 b)$ & 0.47657 & 0.02977 & 0.53443 & $0.07(2)$ & & & & & & \\
\hline $\mathrm{H}(3)$ & 0.07059 & 0.40794 & 0.75715 & $0.052(6)$ & & & & & & \\
\hline $\mathrm{H}(4)$ & 0.04861 & 0.04549 & 0.82972 & $0.078(8)$ & & & & & & \\
\hline
\end{tabular}

Notes: The anisotropic displacement factor exponent takes the form: $-2 \pi^{2}\left[\left(h a^{*}\right)^{2} U_{11}+\ldots+2 h k a^{*} b^{*} U_{12}\right] . U_{\text {eq }}$ is defined as one third the trace of the orthogonalized $U_{i j}$ tensor. $\mathrm{H}$-site coordinates fixed to the values from the neutron structure refinement (Table $3 \mathrm{~b}$ ), their thermal parameters refined isotropically.

TABLE 3b. Atomic coordinates and displacement parameters $\left(\AA^{2}\right)$ of brazilianite based on the neutron structure refinement

\begin{tabular}{|c|c|c|c|c|c|c|c|c|c|c|}
\hline & $x / a$ & $y / b$ & $c / z$ & $U_{\text {eq }}$ & $U_{11}$ & $U_{22}$ & $U_{33}$ & $U_{12}$ & $U_{13}$ & $U_{23}$ \\
\hline $\mathrm{Na}$ & $0.30320(11)$ & $0.07526(10)$ & $0.03507(15)$ & $0.0230(2)$ & $0.0378(5)$ & $0.0152(4)$ & $0.0168(4)$ & $-0.0064(4)$ & $0.0068(4)$ & $0.0002(3)$ \\
\hline $\mathrm{Al}(1)$ & $0.04311(6)$ & $0.22082(7)$ & $0.56153(10)$ & $0.0047(1)$ & $0.0047(2)$ & $0.0054(3)$ & $0.0040(3)$ & $0.0000(2)$ & $0.0009(2)$ & $-0.0010(2)$ \\
\hline $\mathrm{Al}(2)$ & $0.26289(6)$ & $0.06763(7)$ & $0.50793(10)$ & $0.0041(1)$ & $0.0029(2)$ & $0.0047(3)$ & $0.0048(3)$ & $0.0000(2)$ & $0.0005(2)$ & $-0.0004(2)$ \\
\hline $\operatorname{Al}(3)$ & $0.45954(6)$ & $0.25430(7)$ & $0.43278(10)$ & $0.0039(1)$ & $0.0039(2)$ & $0.0048(2)$ & $0.0032(3)$ & $0.0001(2)$ & $0.0010(2)$ & $0.0004(2)$ \\
\hline$P(1)$ & $0.18042(4)$ & $0.31237(5)$ & $0.23765(7)$ & $0.00359(7)$ & $0.0029(2)$ & $0.0046(2)$ & $0.0032(2)$ & $0.0003(1)$ & $0.0000(1)$ & $0.0004(1)$ \\
\hline$P(2)$ & $0.31242(4)$ & $0.32789(5)$ & $0.75398(7)$ & $0.00331(7)$ & $0.0031(2)$ & $0.0037(2)$ & $0.0032(2)$ & $-0.0004(1)$ & $0.0006(1)$ & $-0.0008(1)$ \\
\hline $\mathrm{O}(1)$ & $0.10308(4)$ & $0.07987(4)$ & $0.44925(6)$ & $0.00550(7)$ & $0.0032(1)$ & $0.0062(2)$ & $0.0069(2)$ & $0.0003(1)$ & $0.0000(1)$ & $-.0026(1)$ \\
\hline $\mathrm{O}(2)$ & $0.42380(4)$ & $0.10065(4)$ & $0.56264(6)$ & $0.00571(7)$ & $0.0044(2)$ & $0.0064(2)$ & $0.0063(2)$ & $-0.0007(1)$ & $0.0004(1)$ & $0.0017(1)$ \\
\hline $\mathrm{O}(3)$ & $0.00288(4)$ & $0.35011(4)$ & $0.72467(6)$ & $0.00576(7)$ & $0.0063(2)$ & $0.0060(2)$ & $0.0052(2)$ & $-0.0005(1)$ & $0.0016(1)$ & $-0.0010(1)$ \\
\hline $\mathrm{O}(4)$ & $0.49766(4)$ & $0.38570(4)$ & $0.26966(6)$ & $0.00549(7)$ & $0.0062(2)$ & $0.0060(2)$ & $0.0044(2)$ & $-0.0002(1)$ & $0.0009(1)$ & $0.0007(1)$ \\
\hline $\mathrm{O}(5)$ & $0.11452(4)$ & $0.23958(5)$ & $0.06717(7)$ & $0.00685(7)$ & $0.0050(2)$ & $0.0098(2)$ & $0.0052(2)$ & $0.0001(1)$ & $-0.0015(1)$ & $-0.0019(1)$ \\
\hline $\mathrm{O}(6)$ & $0.28757(4)$ & $0.22174(4)$ & $0.31817(6)$ & $0.00495(7)$ & $0.0037(1)$ & $0.0058(2)$ & $0.0051(2)$ & $0.0013(1)$ & $-0.0003(1)$ & $0.0003(1)$ \\
\hline $\mathrm{O}(7)$ & $0.22596(4)$ & $0.21374(4)$ & $0.68144(6)$ & $0.00501(7)$ & $0.0050(1)$ & $0.0050(2)$ & $0.0050(2)$ & $-0.0015(1)$ & $0.0007(1)$ & $-0.0015(1)$ \\
\hline $\mathrm{O}(8)$ & $0.38765(4)$ & $0.28028(4)$ & $0.93474(7)$ & $0.00668(7)$ & $0.0047(2)$ & $0.0097(2)$ & $0.0051(2)$ & $0.0004(1)$ & $-0.0014(1)$ & $0.0014(1)$ \\
\hline $\mathrm{O}(9)$ & $0.10001(4)$ & $0.34063(4)$ & $0.39249(7)$ & $0.00635(7)$ & $0.0068(2)$ & $0.0065(2)$ & $0.0064(2)$ & $0.0012(1)$ & $0.0036(1)$ & $0.0010(1)$ \\
\hline $\mathrm{O}(10)$ & $0.39156(4)$ & $0.36707(4)$ & $0.60208(7)$ & $0.00639(7)$ & $0.0070(2)$ & $0.0072(2)$ & $0.0055(2)$ & $-0.0018(1)$ & $0.0030(1)$ & $-0.0007(1)$ \\
\hline $\mathrm{O}(11)$ & $0.22615(4)$ & $0.44667(4)$ & $0.18277(7)$ & $0.00711(7)$ & $0.0087(2)$ & $0.0059(2)$ & $0.0071(2)$ & $-0.0011(1)$ & $0.0021(1)$ & $0.0023(1)$ \\
\hline $\mathrm{O}(12)$ & $0.23591(4)$ & $0.44861(4)$ & $0.79057(7)$ & $0.00594(7)$ & $0.0058(2)$ & $0.0054(2)$ & $0.0065(2)$ & $0.0012(1)$ & $0.0001(1)$ & $-0.0021(1)$ \\
\hline$H(1)$ & $0.06558(9)$ & $0.01328(10)$ & $0.36283(15)$ & $0.0214(2)$ & $0.0184(4)$ & $0.0214(4)$ & $0.0232(4)$ & $-0.0038(3)$ & $-0.0016(3)$ & $-0.0098(3)$ \\
\hline $\mathrm{H}(2 \mathrm{a})$ & $0.46380(18)$ & $0.10176(22)$ & $0.69397(27)$ & $0.0249(6)$ & $0.0232(9)$ & $0.0351(11)$ & $0.0147(8)$ & $-0.0035(7)$ & $-0.0041(6)$ & $0.0069(7)$ \\
\hline $\mathrm{H}(2 \mathrm{~b})$ & $0.4766(2)$ & $0.0298(2)$ & $0.5344(4)$ & $0.0250(7)$ & $0.0132(9)$ & $0.0160(10)$ & $0.0468(16)$ & $0.0053(6)$ & $0.0074(8)$ & $0.0044(9)$ \\
\hline $\mathrm{H}(3)$ & $0.07060(11)$ & $0.40794(12)$ & $0.75715(18)$ & $0.0299(2)$ & $0.0329(5)$ & $0.0313(5)$ & $0.0266(5)$ & $-0.0211(5)$ & $0.0072(4)$ & $-0.0090(4)$ \\
\hline $\mathrm{H}(4)$ & $0.04861(10)$ & $0.04550(11)$ & $0.82972(15)$ & $0.0233(2)$ & $0.0255(4)$ & $0.0234(4)$ & $0.0201(4)$ & $0.0117(4)$ & $-0.0003(3)$ & $0.0032(3)$ \\
\hline
\end{tabular}

Notes: The anisotropic displacement factor exponent takes the form: $-2 \pi^{2}\left[\left(h a^{*}\right)^{2} U_{11}+\ldots+2 h k a^{*} b^{*} U_{12}\right]$. $U_{\text {eq }}$ is defined as one third the trace of the orthogonalized $U_{i j}$ tensor. Refined site occupancy factors of $\mathrm{H}(2 \mathrm{a})$ and $\mathrm{H}(2 \mathrm{~b})$ are $0.546(6)$ and $0.446(6)$, respectively.

and 2844 unique reflections with $F_{\mathrm{o}}>4 \sigma\left(F_{\mathrm{o}}\right)$ (Table 2). Atomic positions and displacement parameters $\left(U_{\mathrm{ij}}\right)$ are listed in Table $3 b$. Principal root-mean-square components of the atomic displacement parameters are given in Table $4 \mathrm{~b}$. Bond lengths and angles are listed in Table 5.

\section{DISCUSSION AND CONCLUDING REMARKS}

The EPMA-WDS analysis shows that our sample of brazilianite from Telírio approaches an almost ideal composition [i.e., $\mathrm{NaAl}_{3}\left(\mathrm{PO}_{4}\right)_{2}(\mathrm{OH})_{4}$ ]. $\mathrm{Na}$ can partially be replaced by $\mathrm{K}$ (or $\mathrm{Ca}$. Some $\mathrm{Fe}^{3+}$ and $\mathrm{Mg}$ may replace $\mathrm{Al}$ at the octahedral sites (Table 1).

The single-crystal X-ray and neutron structure refinements of this study confirm the general structure model of brazilianite described by Gatehouse and Miskin (1974). The building-block units of the brazilianite structure consist of chains of edge sharing trans $-\mathrm{AlO}_{4}(\mathrm{OH})_{2}$ [i.e., around $\left.\mathrm{Al}(2)\right]$ and trans $-\mathrm{AlO}_{3}(\mathrm{OH})_{3}$ [i.e., about $\mathrm{Al}(1)$ and $\mathrm{Al}(3)$ ] octahedra. The two chains are connected, via corner-sharing, by P-tetrahedra to form a three-dimensional framework, with $\mathrm{Na}$ atoms located in distorted cavities running along [100] (Fig. 1). The Na-polyhedron, here described with a coordination number of 9 (with $\mathrm{Na}^{-} \mathrm{O}_{\max } \sim 3.11 \AA$; Fig. 2, Table 5), is strongly distorted. Gatehouse and Miskin (1974) suggested that the distortion of the Na-polyhedron might be due to the $\mathrm{H}$ sites in the [100]-cavity: the effect of mutual repulsion forces the $\mathrm{Na}$ site to one side of the cavity, leading to a stronger $\mathrm{Na}-\mathrm{O}$ interaction with oxygen sites on one side of the cavity than on the other. This can now be confirmed by our neutron structure refinement, since $\mathrm{Na}-\mathrm{H}(4)$ distance is $\sim 3.06 \AA, \mathrm{Na}-\mathrm{H}(3)$ is $\sim 3.16$ $\AA$, and $\mathrm{Na}-\mathrm{H}(2)$ is $\sim 3.21 \AA$, and $\mathrm{H}(4), \mathrm{H}(3)$, and $\mathrm{H}(2)$ lie on the 
TABLE 4a. Principal root-mean-square components (R1, R2, and R3 $\times 10^{2} \AA$ ) of the atomic displacement parameters based on the X-ray structure refinement

\begin{tabular}{lcccc}
\hline Site & $\mathrm{R} 1$ & $\mathrm{R} 2$ & $\mathrm{R} 3$ & $\mathrm{R} 1 / \mathrm{R} 3$ \\
\hline $\mathrm{Na}$ & $20.4(1)$ & $13.0(1)$ & $11.6(2)$ & 1.76 \\
$\mathrm{Al}(1)$ & $8.2(1)$ & $8.1(1)$ & $6.5(2)$ & 1.26 \\
$\mathrm{Al}(2)$ & $8.1(1)$ & $7.5(1)$ & $7.1(1)$ & 1.14 \\
$\mathrm{Al}(3)$ & $8.1(1)$ & $7.7(1)$ & $6.3(2)$ & 1.27 \\
$\mathrm{P}(1)$ & $7.8(1)$ & $7.0(1)$ & $6.48(8)$ & 1.21 \\
$\mathrm{P}(2)$ & $7.4(1)$ & $6.9(1)$ & $6.40(8)$ & 1.16 \\
$\mathrm{O}(1)$ & $9.6(3)$ & $7.8(3)$ & $6.9(4)$ & 1.38 \\
$\mathrm{O}(2)$ & $9.2(3)$ & $8.5(3)$ & $8.0(3)$ & 1.15 \\
$\mathrm{O}(3)$ & $9.9(2)$ & $8.0(4)$ & $7.4(3)$ & 1.34 \\
$\mathrm{O}(4)$ & $9.5(3)$ & $8.5(3)$ & $7.5(3)$ & 1.26 \\
$\mathrm{O}(5)$ & $10.9(3)$ & $9.4(3)$ & $7.5(3)$ & 1.45 \\
$\mathrm{O}(6)$ & $8.9(3)$ & $8.3(3)$ & $8.0(3)$ & 1.12 \\
$\mathrm{O}(7)$ & $9.4(3)$ & $8.4(3)$ & $7.0(4)$ & 1.34 \\
$\mathrm{O}(8)$ & $10.5(2)$ & $8.7(3)$ & $7.4(3)$ & 1.42 \\
$\mathrm{O}(9)$ & $10.4(2)$ & $8.5(3)$ & $7.1(4)$ & 1.48 \\
$\mathrm{O}(10)$ & $10.6(2)$ & $8.4(3)$ & $6.9(4)$ & 1.53 \\
$\mathrm{O}(11)$ & $10.5(2)$ & $9.6(3)$ & $7.8(4)$ & 1.34 \\
$\mathrm{O}(12)$ & $9.6(3)$ & $8.5(2)$ & $7.8(3)$ & 1.23 \\
\hline
\end{tabular}

TABLE 4b. Principal root-mean-square components (R1, R2, and R3 $\times 10^{2} \AA$ ) of the atomic displacement parameters based on the neutron structure refinement

\begin{tabular}{lcccc}
\hline Site & $\mathrm{R} 1$ & $\mathrm{R} 2$ & $\mathrm{R} 3$ & $\mathrm{R} 1 / \mathrm{R} 3$ \\
\hline $\mathrm{Na}$ & $19.9(1)$ & $12.8(2)$ & $11.3(2)$ & 1.76 \\
$\mathrm{Al}(1)$ & $7.7(1)$ & $6.9(1)$ & $5.8(3)$ & 1.32 \\
$\mathrm{Al}(2)$ & $7.2(2)$ & $6.6(2)$ & $5.3(2)$ & 1.36 \\
$\mathrm{Al}(3)$ & $7.0(1)$ & $6.4(2)$ & $5.2(3)$ & 1.35 \\
$\mathrm{P}(1)$ & $6.9(1)$ & $5.8(2)$ & $5.1(1)$ & 1.34 \\
$\mathrm{P}(2)$ & $6.6(2)$ & $5.5(2)$ & $5.1(2)$ & 1.29 \\
$\mathrm{O}(1)$ & $9.7(1)$ & $6.2(2)$ & $5.66(9)$ & 1.71 \\
$\mathrm{O}(2)$ & $9.1(1)$ & $6.93(7)$ & $6.3(2)$ & 1.44 \\
$\mathrm{O}(3)$ & $8.54(6)$ & $7.5(1)$ & $6.6(2)$ & 1.30 \\
$\mathrm{O}(4)$ & $8.0(1)$ & $7.8(1)$ & $6.3(2)$ & 1.26 \\
$\mathrm{O}(5)$ & $10.3(1)$ & $8.2(1)$ & $5.48(9)$ & 1.89 \\
$\mathrm{O}(6)$ & $8.1(1)$ & $7.5(1)$ & $5.29(9)$ & 1.52 \\
$\mathrm{O}(7)$ & $8.37(6)$ & $7.1(1)$ & $5.57(9)$ & 1.50 \\
$\mathrm{O}(8)$ & $10.0(1)$ & $8.4(1)$ & $5.39(9)$ & 1.87 \\
$\mathrm{O}(9)$ & $9.9(1)$ & $7.6(1)$ & $5.9(2)$ & 1.67 \\
$\mathrm{O}(10)$ & $9.8(1)$ & $7.7(1)$ & $5.9(2)$ & 1.66 \\
$\mathrm{O}(11)$ & $9.5(1)$ & $9.4(1)$ & $5.8(2)$ & 1.64 \\
$\mathrm{O}(12)$ & $9.4(1)$ & $7.42(7)$ & $6.0(2)$ & 1.56 \\
$\mathrm{H}(1)$ & $18.0(1)$ & $14.8(1)$ & $9.9(2)$ & 1.82 \\
$\mathrm{H}(2 \mathrm{a})$ & $19.9(3)$ & $15.5(3)$ & $10.5(4)$ & 1.90 \\
$\mathrm{H}(2 \mathrm{~b})$ & $21.8(4)$ & $13.6(3)$ & $9.5(5)$ & 2.30 \\
$\mathrm{H}(3)$ & $23.4(1)$ & $15.7(2)$ & $10.2(2)$ & 2.28 \\
$\mathrm{H}(4)$ & $19.1(1)$ & $14.9(2)$ & $10.6(2)$ & 1.79 \\
\hline & & & &
\end{tabular}

same side of the cavity. Both the X-ray and neutron structure refinements show that the Al-octahedra appear to be significantly distorted, with $\Delta[\mathrm{Al}(1)-\mathrm{O}]_{\max } \sim 0.32 \AA, \Delta[\mathrm{Al}(2)-\mathrm{O}]_{\max } \sim 0.31 \AA$, and $\Delta[\mathrm{Al}(3)-\mathrm{O}]_{\max } \sim 0.17 \AA$ (i.e., the difference between the longest and the shortest Al-O distances, based on the X-ray structure refinement) (Table 5). The longest $\mathrm{Al}-\mathrm{O}$ bond distances are those with the bridging oxygen shared between two Al-octahedra and one P-tetrahedron [i.e., $\mathrm{O}(6)$ and $\mathrm{O}(7)$, Table 5]. The shortest Al-O bond distances are those with oxygen atoms of $\mathrm{OH}$-groups [i.e., $\mathrm{O}(1), \mathrm{O}(2), \mathrm{O}(3)$, and $\mathrm{O}(4)$, Table 5]. P-tetrahedra appear to be less distorted, as $\Delta[\mathrm{P}(1)-\mathrm{O}]_{\max } \sim 0.044 \AA$ and $\Delta[\mathrm{P}(2)-\mathrm{O}]_{\max } \sim$ $0.036 \AA$ (i.e., the difference between the longest and the shortest $\mathrm{P}-\mathrm{O}$ distances, based on the X-ray structure refinement) (Table 5).

The neutron structure refinement of this study provides an unambiguous location of the $\mathrm{H}$-sites, allowing the description of the H-bonding scheme in the brazilianite structure. Five independent $\mathrm{H}$ sites were located, here labeled $\mathrm{H}(1), \mathrm{H}(2 \mathrm{a}), \mathrm{H}(2 \mathrm{~b}), \mathrm{H}(3)$, and $\mathrm{H}(4)$. The configuration of the $\mathrm{OH}$ groups [i.e., $\mathrm{O}(1)-\mathrm{H}(1)$, $\mathrm{O}(2)-\mathrm{H}(2 \mathrm{a}), \mathrm{O}(2)-\mathrm{H}(2 \mathrm{~b}), \mathrm{O}(3)-\mathrm{H}(3), \mathrm{O}(4)-\mathrm{H}(4)]$, along with the
TABLE 5. Relevant bond distances $(\AA)$ and angles $\left({ }^{\circ}\right)$ in the brazilianite structure based on the X-ray structure refinement (XSR) and the neutron structure refinement (NSR)

\begin{tabular}{|c|c|c|}
\hline & XSR & NSR \\
\hline $\mathrm{Na}-\mathrm{O}(8)$ & $2.432(1)$ & $2.433(1)$ \\
\hline $\mathrm{Na}-\mathrm{O}(11)$ & $2.450(1)$ & $2.452(1)$ \\
\hline $\mathrm{Na}-\mathrm{O}(6)$ & $2.526(1)$ & $2.528(1)$ \\
\hline $\mathrm{Na}-\mathrm{O}(3)$ & $2.581(1)$ & $2.581(1)$ \\
\hline $\mathrm{Na}-\mathrm{O}(12)$ & $2.631(1)$ & $2.637(1)$ \\
\hline $\mathrm{Na}-\mathrm{O}(9)$ & $2.642(1)$ & $2.643(1)$ \\
\hline $\mathrm{Na}-\mathrm{O}(5)$ & $2.728(1)$ & $2.731(1)$ \\
\hline $\mathrm{Na}-\mathrm{O}(7)$ & $2.909(1)$ & $2.916(1)$ \\
\hline $\mathrm{Na}-\mathrm{O}(10)$ & $3.106(1)$ & $3.110(1)$ \\
\hline$<\mathrm{Na}-\mathrm{O}\rangle$ & 2.667 & 2.670 \\
\hline $\mathrm{Al}(1)-\mathrm{O}(1)$ & $1.809(1)$ & $1.8106(9)$ \\
\hline $\mathrm{Al}(1)-\mathrm{O}(3)$ & $1.841(1)$ & $1.8464(9)$ \\
\hline $\mathrm{Al}(1)-\mathrm{O}(8)$ & $1.864(1)$ & $1.8620(9)$ \\
\hline $\mathrm{Al}(1)-\mathrm{O}(9)$ & $1.877(1)$ & $1.8794(9)$ \\
\hline $\mathrm{Al}(1)-\mathrm{O}(4)$ & $1.954(1)$ & $1.9536(9)$ \\
\hline $\mathrm{Al}(1)-\mathrm{O}(7)$ & $2.125(1)$ & $2.1242(9)$ \\
\hline$<\mathrm{Al}(1)-\mathrm{O}\rangle$ & 1.912 & 1.9127 \\
\hline $\mathrm{Al}(2)-\mathrm{O}(1)$ & $1.794(1)$ & $1.7963(8)$ \\
\hline $\mathrm{Al}(2)-\mathrm{O}(2)$ & $1.833(1)$ & $1.8324(9)$ \\
\hline $\mathrm{Al}(2)-\mathrm{O}(11)$ & $1.845(1)$ & $1.8458(9)$ \\
\hline $\mathrm{Al}(2)-\mathrm{O}(12)$ & $1.873(1)$ & $1.8738(9)$ \\
\hline $\mathrm{Al}(2)-\mathrm{O}(7)$ & $2.003(1)$ & $2.0071(9)$ \\
\hline $\mathrm{Al}(2)-\mathrm{O}(6)$ & $2.106(1)$ & $2.1081(9)$ \\
\hline$<\mathrm{Al}(2)-\mathrm{O}\rangle$ & 1.909 & 1.9106 \\
\hline $\mathrm{Al}(3)-\mathrm{O}(4)$ & $1.853(1)$ & $1.8541(9)$ \\
\hline $\mathrm{Al}(3)-\mathrm{O}(2)$ & $1.877(1)$ & $1.8825(9)$ \\
\hline $\mathrm{Al}(3)-\mathrm{O}(5)$ & $1.883(1)$ & $1.8787(9)$ \\
\hline $\mathrm{Al}(3)-\mathrm{O}(10)$ & $1.895(1)$ & $1.8923(9)$ \\
\hline $\mathrm{Al}(3)-\mathrm{O}(3)$ & $1.932(1)$ & $1.9333(9)$ \\
\hline $\mathrm{Al}(3)-\mathrm{O}(6)$ & $2.025(1)$ & $2.0275(9)$ \\
\hline$<\mathrm{Al}(3)-\mathrm{O}>$ & 1.911 & 1.9114 \\
\hline$P(1)-O(11)$ & $1.523(1)$ & $1.5256(7)$ \\
\hline$P(1)-O(5)$ & $1.527(1)$ & $1.5289(7)$ \\
\hline $\mathrm{P}(1)-\mathrm{O}(9)$ & $1.540(1)$ & $1.5386(7)$ \\
\hline$P(1)-O(6)$ & $1.567(1)$ & $1.5654(7)$ \\
\hline$\langle P(1)-O\rangle$ & 1.539 & 1.5396 \\
\hline $\mathrm{P}(2)-\mathrm{O}(8)$ & $1.523(1)$ & $1.5251(7)$ \\
\hline$P(2)-O(10)$ & $1.535(1)$ & $1.5373(7)$ \\
\hline$P(2)-O(12)$ & $1.537(1)$ & $1.5386(7)$ \\
\hline $\mathrm{P}(2)-\mathrm{O}(7)$ & $1.559(1)$ & $1.5578(7)$ \\
\hline$\langle\mathrm{P}(2)-\mathrm{O}\rangle$ & 1.539 & 1.5397 \\
\hline $\mathrm{O}(1)-\mathrm{H}(1)$ & $0.974(1)$ & $0.973(1)$ \\
\hline $\mathrm{O}(1)-\mathrm{H}(1)^{*}$ & & 0.994 \\
\hline $\mathrm{O}(1) \ldots \mathrm{O}(4)$ & $2.672(1)$ & $2.673(1)$ \\
\hline $\mathrm{H}(1) \ldots \mathrm{O}(4)$ & $1.701(1)$ & $1.703(1)$ \\
\hline $\mathrm{O}(1)-\mathrm{H}(1) \ldots \mathrm{O}(4)$ & $174.1(1)$ & $174.2(1)$ \\
\hline $\mathrm{O}(2)-\mathrm{H}(2 \mathrm{a})$ & $0.983(1)$ & $0.984(1)$ \\
\hline $\mathrm{O}(2)-\mathrm{H}(2 \mathrm{a})^{*}$ & & 1.010 \\
\hline $\mathrm{O}(2) \cdots \mathrm{O}(9)$ & $2.929(1)$ & $2.933(1)$ \\
\hline $\mathrm{H}(2 \mathrm{a}) \cdots \mathrm{O}(9)$ & $2.031(1)$ & $2.033(2)$ \\
\hline $\mathrm{O}(2)-\mathrm{H}(2 \mathrm{a}) \cdots \mathrm{O}(9)$ & $151.0(1)$ & $151.2(2)$ \\
\hline $\mathrm{O}(2)-\mathrm{H}(2 \mathrm{~b})$ & $0.973(1)$ & $0.970(1)$ \\
\hline $\mathrm{O}(2)-\mathrm{H}(2 \mathrm{~b})^{*}$ & & 0.997 \\
\hline $\mathrm{O}(2) \cdots \mathrm{O}(2)$ & $2.886(1)$ & $2.881(1)$ \\
\hline $\mathrm{H}(2 \mathrm{~b}) \cdots \mathrm{O}(2)$ & $1.922(1)$ & $1.919(3)$ \\
\hline $\mathrm{O}(2)-\mathrm{H}(2 \mathrm{~b}) \cdots \mathrm{O}(2)$ & $170.8(1)$ & $170.8(2)$ \\
\hline $\mathrm{O}(3)-\mathrm{H}(3)$ & $0.968(1)$ & $0.966(1)$ \\
\hline $\mathrm{O}(3)-\mathrm{H}(3)^{*}$ & & 1.001 \\
\hline $\mathrm{O}(3) \cdots \mathrm{O}(12)$ & $2.785(1)$ & $2.788(1)$ \\
\hline $\mathrm{H}(3) \cdots \mathrm{O}(12)$ & $1.886(1)$ & $1.889(1)$ \\
\hline $\mathrm{O}(3)-\mathrm{H}(3) \cdots \mathrm{O}(12)$ & $153.3(1)$ & $153.6(1)$ \\
\hline $\mathrm{O}(4)-\mathrm{H}(4)$ & $0.967(1)$ & $0.968(1)$ \\
\hline $\mathrm{O}(4)-\mathrm{H}(4)^{*}$ & & 0.992 \\
\hline $\mathrm{O}(4) \cdots \mathrm{O}(10)$ & $2.894(1)$ & $2.898(1)$ \\
\hline $\mathrm{H}(4) \cdots \mathrm{O}(10)$ & $1.969(1)$ & $1.972(1)$ \\
\hline $\mathrm{O}(4)-\mathrm{H}(4) \cdots \mathrm{O}(10)$ & $159.4(1)$ & $159.4(1)$ \\
\hline
\end{tabular}




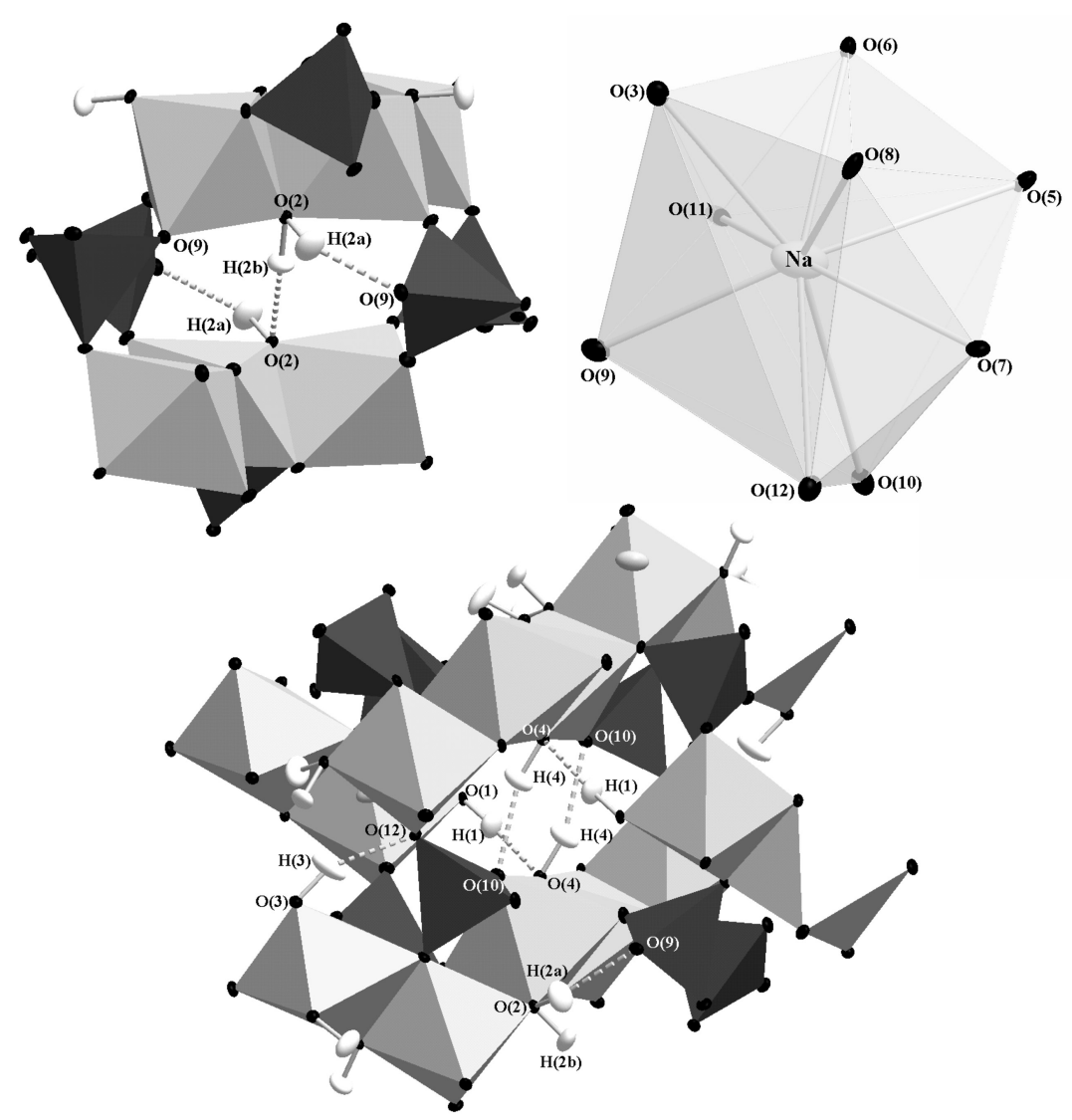

Figure 2. Hydrogen sites location, H-bonding scheme, and configuration of the Na-polyhedron in the structure of brazilianite based on the neutron structure refinement of this study. The sites $\mathrm{H}(2 \mathrm{a})$ and $\mathrm{H}(2 \mathrm{~b})$ are mutually exclusive. Thermal ellipsoid probability factor: $60 \%$.

hydrogen bonding scheme, are now well defined (Fig. 2, Table 5). $\mathrm{O}(1), \mathrm{O}(2), \mathrm{O}(3)$, and $\mathrm{O}(4)$ act as donors, whereas $\mathrm{O}(2)$, $\mathrm{O}(4), \mathrm{O}(9)$, and $\mathrm{O}(12)$ as acceptors. Symmetry-related $\mathrm{O}(2)$ act both as donor and as acceptor of H-bonds. The O-H distances corrected for "riding motion" (Busing and Levy 1964), range between $\sim 0.992$ and $\sim 1.010 \AA$, the $\mathrm{O} \cdots \mathrm{O}$ distances between $\sim 2.67$ and $\sim 2.93 \AA$, and the $\mathrm{O}-\mathrm{H} \cdots \mathrm{O}$ angles between $\sim 151^{\circ}$ and $\sim 174^{\circ}$ (Table 5). The $\mathrm{H}(2 \mathrm{a})$ and $\mathrm{H}(2 \mathrm{~b})$ are only $\sim 1.37 \AA$ apart. The neutron structure refinement was carried out without any restraint on the site occupancy factors (s.o.f.) of $\mathrm{H}(2 \mathrm{a})$ and $\mathrm{H}(2 \mathrm{~b})$, leading to s.o.f. $(\mathrm{H} 2 \mathrm{a})=0.546(6)$ and s.o.f. $(\mathrm{H} 2 \mathrm{~b})=0.446(6)$, respectively (Table $3 \mathrm{~b}$ ). We can thus consider a general s.o.f. of $50 \%$ each for $\mathrm{H}(2 \mathrm{a})$ and $\mathrm{H}(2 \mathrm{~b})$, therefore the two $\mathrm{H}$ sites are mutually exclusive. Additional test refinements were performed to check if this H-site splitting reflects a lower symmetry than $P 2_{1} / n$, but without success. The key to understand the splitting of $\mathrm{H}(2 \mathrm{a})$ and $\mathrm{H}(2 \mathrm{~b})$ in two mutually exclusive sites is in the $\mathrm{H}$ bonding scheme of the structure. In fact, if only one "virtual" $\mathrm{H}(2)$ site should occur, located between $\mathrm{H}(2 \mathrm{a})$ and $\mathrm{H}(2 \mathrm{~b})$, it would have an energetically unfavorable $\mathrm{H}$-bond configuration, with $\mathrm{O}(2)-\mathrm{H}(2) \cdots \mathrm{O}(9) \sim 113^{\circ}$ and $\mathrm{O}(2)-\mathrm{H}(2) \cdots \mathrm{O}(2) \sim 127^{\circ}$, whereas the split site configuration yields $\mathrm{O}(2)-\mathrm{H}(2 \mathrm{a}) \cdots \mathrm{O}(9) \sim$ $151^{\circ}$ and $\mathrm{O}(2)-\mathrm{H}(2 \mathrm{~b}) \cdots \mathrm{O}(2) \sim 171^{\circ}$ (Table 5).

The principal root-mean-square components of the atomic displacement parameters of the $\mathrm{H}$ sites show a slightly pronounced anisotropy, in particular for the $\mathrm{H}(2 \mathrm{~b})$ and $\mathrm{H}(3)$ sites (Table 4b). Both the X-ray and the neutron structure refinements show that: (1) the Na site has the highest displacement anisotropy, about the equilibrium position, among the cation sites, and (2) $\mathrm{O}(5), \mathrm{O}(8), \mathrm{O}(9)$, and $\mathrm{O}(10)$ sites have the highest anisotropy among all the oxygen sites, and they are all bridging oxygen between P-tetrahedra and Al-octahedra (Tables 4a, 4b, and 5).

It is interesting to point out how the structure of brazilianite and that of wardite [ideally $\mathrm{NaAl}_{3}\left(\mathrm{PO}_{4}\right)_{2}(\mathrm{OH})_{4} \cdot 2 \mathrm{H}_{2} \mathrm{O}$, Fanfani et al. 1970] are significantly different, as highlighted by Gatehouse and Miskin (1974), despite the "chemical similarity." As in brazilianite, also in wardite the primary building units are P-tetrahedra and Al-octahedra. However, in wardite P-tetrahedra join the sheets of corner-linked Al-octahedra, whereas in brazilianite edge-sharing Al-octahedra occur. In wardite, $\mathrm{H}_{2} \mathrm{O}$ is not "zeolitic": the molecule is coordinated to $\mathrm{Al}$, and not to $\mathrm{Na}$ in the [100]-cavity. This leads to a different crystal structure of the two mentioned minerals.

\section{ACKNOWLEDGMENTS}

This work is based upon experiments performed at the HEiDI instrument operated by RWTH Aachen/FZ Jülich (Jülich Aachen Research Alliance JARA) at the Heinz Maier-Leibnitz Zentrum (MLZ), Garching, Germany. This research project has been supported by the European Commission under the 7th Framework Programme through the "Research Infrastructures" action of the Capacities Programme, NMI3-II, Grant number 283883. The authors kindly thank Sergio Varvello, who provided the sample of brazilianite, and Andrea Risplendente, for his assistance during the EPMA analyses. W. Simmons, F. Hatert, and the Associate Editor A. Celestian are thanked for the revision of the manuscript. This study was founded by the Italian Ministry of Education, MIUR-Project: 2010EARRRZ_003.

\section{REFERENCES CITED}

Agilent Technologies (2012) Xcalibur CCD system, CrysAlis Software system. Agilent Technologies, Yarnton, Oxfordshire, U.K.

Busing, W.R., and Levy, H.A. (1964) The effect of thermal motion on the estimation of 
bond lengths from diffraction measurements. Acta Crystallographica, 17, 142-146.

Černý, P., and Ercit, S. (2005) The classification of granitic pegmatites revisited. Canadian Mineralogist, 43, 2005-2026.

Fanfani, L., Nunzi, A., and Zanazzi, P.F. (1970) The crystal structure of wardite. Mineralogical Magazine, 37, 598-605.

Farrugia, L.J. (1999) WinGX suite for small-molecule single-crystal crystallography. Journal of Applied Crystallography, 32, 837-838.

Frondel, C., and Lindberg, M.L. (1948) Second occurrence of brazilianite. American Mineralogist, 33, 135-141.

Gatehouse, B.M., and Miskin, B.K. (1974) The crystal structure of brazilianite, $\mathrm{NaAl}_{3}\left(\mathrm{PO}_{4}\right)_{2}(\mathrm{OH})_{4}$. Acta Crystallographica, 30, 1311-1317.

Gatta, G.D., Vignola, P., McIntyre, G.J., and Diella, V. (2010) On the crystal chemistry of londonite $\left[(\mathrm{Cs}, \mathrm{K}, \mathrm{Rb}) \mathrm{Al}_{4} \mathrm{Be}_{5} \mathrm{~B}_{11} \mathrm{O}_{28}\right]$ : a single-crystal neutron diffraction study at 300 and $20 \mathrm{~K}$. American Mineralogist, 95, 1467-1472.

Gatta, G.D., Danisi, R.M., Adamo, I., Meven, M., and Diella, V. (2012a) A singlecrystal neutron and X-ray diffraction study of elbaite. Physics and Chemistry of Minerals, 39, 577-588.

Gatta, G.D., Adamo, I., Meven, M., and Lambruschi, E. (2012b) A single-crystal neutron and X-ray diffraction study of pezzottaite, $\mathrm{Cs}\left(\mathrm{Be}_{2} \mathrm{Li}\right) \mathrm{Al}_{2} \mathrm{Si}_{6} \mathrm{O}_{18}$. Physics and Chemistry of Minerals, 39, 829-840.

Hurlbut, C.S., and Weichel, J.W. (1946) Additional data on brazilianite. American Mineralogist, 31, 507

Larson, A.C. (1967) Inclusion of secondary extinction in least-squares calculations. Acta Crystallographica, 23, 664-665.

Macrì, M. (2011) Brasilianite, una pietra luminosa che ha vissuto per lunghi secoli al buio. Rivista Gemmologica Italiana, 6-1, 24-26.

O'Donoghue, M. (2006) Gems, Sixth Edition, 873 p. Butterworth-Heinemann, Elsevier, Oxford, U.K.

Pecora, W.T., and Fahey, J.J. (1949) The Corrego Frio pegmatite, Minas Gerais: scorzalite and souzalite, two new phosphate minerals. American Mineralogist, 34, 83-93.

Pough, F.H., and Henderson, E.P.(1945) Brazilianite, a new phosphate mineral. American Mineralogist, 30, 572-582.

Rinaldi, R., Liang, and L., Schober, H. (2009) Neutron applications in Earth, energy and environmental sciences. In L. Liang, R. Rinaldi, and H. Schober, Eds., Neutron Applications in Earth, Energy and Environmental Sciences, p. 1-14. Springer Science, New York.

Sears, V.F. (1986) Neutron scattering lengths and cross-sections. In K. Sköld and D.L. Price, Eds., Neutron Scattering, Methods of Experimental Physics, 23A, p. 521-550. Academic Press, New York.

Sheldrick, G.M. (1997) SHELX-97. Programs for crystal structure determination and refinement. University of Göttingen, Germany.

A short history of SHELX. Acta Crystallographica, A64, 112-122.

Wilson, A.J.C., and Prince, E. (1999) International Tables for X-ray Crystallography, Volume C: Mathematical, physical and chemical tables, 2nd edition. Kluwer Academic, Dordrecht, Netherlands.

MANUSCRIPT RECEIVED JANUARY 22, 2013

MANUSCRIPT ACCEPTED APRIL 13, 2013

MANUSCRIPT HANDLED BY AARON CELESTIAN 